\title{
ANALISIS PENERAPAN SISTEM BAGI HASIL PADA PEMBIAYAAN \\ MUDHARABAH DI PT BANK NEGARA INDONESIA SYARIAH CABANG \\ MAKASSAR
}

Fahira Al'ainaa Aswari

fahiraalainaa2283@gmail.com

Institut Bisnis dan Keuangan Nitro Makassar

\begin{abstract}
Abstrak
Penelitian ini berjudul Analisis Penerapan Sistem Bagi Hasil Pada Pembiayaan Mudharabah Di PT Bank Negara Indonesia Syariah cabang Makassar. Penelitian ini bertujuan untuk mengetahui penerapan sistem bagi hasil pada pembiayaan mudharabah yang dilakukan PT Bank Negara Indonesia Syariah cabang Makassar. Penelitian ini menggunakan metode penelitian kualitatif, sehingga menghasilkan data deskriptif. Penelitian ini menggunakan teknik pengumpulan data wawancara dan dokumentasi.

Hasil penelitian ini menunjukkan bahwa penerapan bagi hasil pada pembiayaan mudharabah yang dilakukan PT Bank Negara Indonesia Syariah yaitu menggunakan metode gross profit margin (bagi hasil usaha) untuk rasio pembagian labanya maka pihak PT Bank Negara Indonesia Syariah melihat dari jangka waktu pembiayaan. Pihak Bank tidak meyebutkan berapa porsi antara Bank dan Nasabah melainkan pihak Bank melakukan negosiasi. Jadi penerapan sistem bagi hasil yang diterapkan PT Bank Negara Indonesia Syariah cab Makassar sudah berjalan sesuai dengan fatwa No.07/-DSN-MUI/IV/2000.
\end{abstract}

Kata kunci: bagi hasil, pembiayaan mudharabah. 


\section{PENDAHULUAN}

\section{A. Latar Belakang}

Perbankan merupakan salah satu lembaga keuangan yang mempunyai peran yang penting didalam kehidupan suatu Negara, apalagi Negara yang berkembang seperti Indonesia. Menurut Abdullah (2012) Sistem perbankan merupakan suatu sarana penting dalam peradaban masyarakat modern. Tugas utamanya adalah menghimpun dana dari masyarakat dan menyalurkan dana tersebut kepada peminjam, kemudian digunakan untuk ditanamkan pada sektor produksi atau investasi, disamping digunakan untuk aktivitas ekonomi dan lainnya sehingga dapat tumbuh dan berkembang serta meningkatkan standar kehidupan. Oleh karena itu sistem perbankan memiliki peranan yang sangat mendasar dalam perekonomian dan kehidupan masyarakat.

Indonesia meskipun bukan negara Islam tapi negara muslim yang mayoritas penduduknya beragama Islam, menganggap bahwa Bank Konvensional didalamnya mengandung hal-hal yang bertentangan dengan syariat Islam seperti pada penetapan bunga yang ada di Bank Konvensional, maka dari itu sebagai masyarakat muslim sangat membutuhkan Bank yang berlandasakan dengan syariat Islam.

Maka dari itu untuk memenuhi kebutuhan Masyarakat dalam dunia perbankan maka dibentuklah Bank Syariah. Bank Syariah pertama kali dibentuk ialah Bank Muamalah Indonesia, sejak itulah kehadiran Bank Syariah terus diperbincangkan dan dikembangkan, maka dari itulah dibentuklah Dewan Nasional Syariah untuk memenuhi harapan masyarakat akan kebutuhan masyarakat tentang Bank yang beroperasi berlandasakan syariah Islam.

Berkembangnya bank syariah saat ini merupakan bukti bahwa ajaran agama Islam juga bisa diterapkan dalam kegiatan perekonomian. Hal ini didukung dengan keunggulan sistem bank syariah yang menggunakan skema bagi hasil. Skema bagi hasil atau yang biasa dalam fiqh mu'amalah disebut sebagai transaksi mudharabah merupakan perbedaan antara bank konvensional dan bank syariah. Menurut Muhammad (2008) bank syariah mempunyai core product pembiayaan berupa produk bagi hasil yang dikembangkan dalam produk musyarakah dan mudharabah. Secara terminologi, merujuk Fatwa DSN No. 07/DSN-MUI/IV/2000 tentang Pembiayaan Mudharabah, mudharabah 
adalah akad kerja sama suatu usaha antara dua pihak dimana pihak pertama menyediakan seluruh modal, sedang pihak kedua bertindak selaku pengelola dan keuntungan usaha dibagi di antara mereka sesuai kesepakatan yang dituangkan dalam kontrak.

Didalam pelaksanaan prinsip bagi hasil dalam hal kegiatan penghimpunan dana dalam bank syariah cukup mendapat kepercayaan dari masyarakat, akan tetapi dalam hal penyaluran dana yang dilakukan bank syariah dalam bentuk pembiayaan masih cukup banyak masyarakat yang beranggapan bahwa pembiayaan di bank syariah tidak berbeda dengan kredit di bank konvensional atau belum benar-benar diterapkan sesuai hukum islam.

PT. Bank BNI Syariah Cabang Makassar merupakan salah satu bank syariah di Indonesia yang menjalankan konsep mudharabah berdasarkan PSAK No. 105, akad kerja sama usaha antara dua pihak di mana pihak pertama (pemilik dana) menyediakan seluruh dana, sedangkan pihak kedua (pengelola dana) bertindak selaku pengelola dan keuntungan dibagi di antara mereka sesuai kesepakatan, sedangkan kerugian finansial hanya ditanggung oleh pemilik dana. Bank BNI Syariah Cabang Makassar memberikan pelayanan pembiayaan mudharabah yang berupa pembiayaan untuk usaha produktif,

jangka waktu, tata cara pengembalian dan pembagian keuntungan ditentukan berdasarkan kesepakatan kedua pihak.

Berdasarkan uraian diatas, penulis tertarik untuk melakukan penelitian berjudul "ANALISIS PENERAPAN SISTEM BAGI HASIL PADA PEMBIAYAAN MUDHARABAH DI BANK BNI SYARIAH CABANG MAKASSAR".

\section{B. Rumusan Masalah}

Berdasarkan uraian latar belakang yang dikemukakan di atas, maka yang menjadi rumusan masalah yaitu: Bagaimanakah Sistem Bagi Hasil Pada Pembiayaan Mudharabah yang diterapkan oleh PT. Bank BNI Syariah Cabang Makassar?

\section{Tujuan dan Manfaat Penelitian}

a. Bagi Penulis

Hasil penelitian ini diharapkan berguna bagi penulis untuk menambah pengetahuan dan informasi mengenai penerapan sistem bagi hasil pada pembiayaan mudharabah di Perbankan Syariah. 
b. Bagi Pembaca

Untuk menambah wawasan pembaca tentang penerapan sistem bagi hasil pada pembiayaan mudharabah di PT. Bank BNI Syariah cabang Makassar.

c. Bagi Peneliti Selanjutnya

Dapat memberikan sebuah manfaat, berupa tambahan informasi dan sebagai referensi bacaan untuk melakukan penelitian dengan objek yang sama dimasa yang akan datang.

\section{TINJAUAN PUSTAKA}

\section{Bank Syariah}

\section{Bank Syariah}

\section{a. Pengertian Bank Syariah}

Bank Syariah terdiri atas dua kata, yaitu Bank dan Syariah. Bank adalah badan usaha yang menghimpun dana dari masyarakat dalam bentuk simpanan dan menyalurkan kepada masyarakat dalam bentuk kredit atau bentuk-bentuk lainnya dalam rangka meningkatkan taraf hidup rakyat banyak (Misbach, 2013). Syariah menurut bahasa ialah asy-syari yang artinya meminum air dan menurut istilah hukum-hukum dan aturanaturan Allah disyariahkan buat hambanya untuk diikuti dan hubungan mereka sesama manusia. Jadi yang dimaksud bank syariah adalah lembaga keuangan yang usaha pokoknya memberikan kredit dan jasa-jasa lain dalam lalu lintas pembayaran dengan prinsip-prinsip syariah. Perbankan Syariah adalah segala sesuatu yang menyangkut tentang bank syariah dan unit bank syariah, mencakup kelembagaan, kegiatan usaha serta cara dan proses dalam melaksanakan kegiatan usahanya (Misbach, 2013).

Secara umum, pengertian Bank Syariah (Islamic Bank) adalah bank yang pengoperasiannya disesuaikan dengan prinsip syariat Islam. Saat ini banyak istilah yang diberikan untuk menyebut entitas bank Islam, selain istilah bank Islam itu sendiri, yaitu bank tanpa bunga (interest-freebank), bank tanpa riba (lariba bank), dan bank syariah (shari'a bank).

Menurut Undang-Undang No. 21 tahun 2008 dalam pasal 1 tentang perbankan syariah adalah segala sesuatu yang menyangkut tentang bank syariah dan unit usaha syariah mencakup kelembagaan, kegiatan usaha, serta cara dan proses dalam melaksanakan usahanya. 
berikut dibawah ini dikemukakan beberapa pengertian Bank Islam, yaitu sebagai berikut:

1. Karnaen Perwataadmadja dan Muhammad Syafi'I Antonio, Bank Islam adalah bank yang beroperasi sesuai dengan syariah Islam, yakni bank yang dalam operasinya mengikuti ketentuan-ketentuan syariah Islam khususnya menyangkut tata cara bermuamalah secara Islam. Dalam tata cara bermuamalah itu dijauhi praktik-praktik yang dikhawatirkan mengandung unsur-unsur riba untuk diisi dengan kegiatankegiatan investasi atas dasar bagi hasil dan pembiayaan perdagangan.

2. M. Amin Aziz, bank Islam (bank berdasarkan syariah Islam) adalah lembaga perbankan yang menggunakan sistem dan operasinya berdasarkan syariah Islam. Ini berarti operasi perbankan mengikuti tata cara berusaha maupun perjanjian berusaha berdasarkan al-Qur'an dan Sunnah Rasul Muhammad SAW dan bukan tata cara dan perjanjia berusha yang bukan dituntun oleh al-Qur'an dan Sunnah Rasul Muhammad SAW. Dalam operasinya bank Islam menggunakan sistem bagi hasil penimbalan lainnya yang sesuai dengan syariat Islam, tidak menggunakan bunga.

3. Cholil Uman, Bank Islam adalah sebuah lembaga keuangan yang menjalankan operasinya menurut hukum Islam. Sudah tentu bank Islam tidak memakai sistem bunga, sebab bunga dilarang oleh Islam. Sedangkan bank non Islam adalah sebuah lembaga keuangan yang berfungsi utamanya menghimpun dana untuk disalurkan kepada yang memerlukan dana guna investasi dalam usaha-usaha yang produktif dan lain-lain dengan sistem bunga.

Gagasan mengenai bank syariah telah muncul sejak lama, ditandai dengan banyaknya pemikir-pemikir muslim yang menulis tentang keberadaan bank Islam. Sejarah awal mula kegiatan bank syariah yang pertama sekali dilakukan adalah Pakistan dan Malaysia pada sekitar 1940an. Kemudian di Mesir pada 1963 berdiri Islamic Rural Bank dan masih berskala kecil (Abdullah dan Tanri, 2014). Di Indonesia sangat didambakan kehadiran bank berdasarkan syariah, ketua pengurus muhammadiyah priode 1937-1944 telah menguraikan pendapatnya tentang penggunaan jasa bank konvensional sebagai hal yang terpaksa dilakukan karena umat islam belum mempunyai bank sendiri yang bebas dari riba. Setelah itu muncul ide untuk mendirikan bank yang berdasarkan syariat Islam di 
Indonesia. Kemudian di bicarakan pada seminar nasional Hubungan Indonesia dengan Timur Tengah pada tahun 1974 dan pada tahun 1976 dalam seminar internasional yang dilaksanakan oleh Lembaga Studi Ilmu-Ilmu kemasyarakatan dan Yayasan Bhineka Tunggal Ika. Namun ada beberapa alasan yang menghambat terealisasinya ide ini yaitu : operasi bank syariah yang menerapkan prinsip bagi hasil belum diatur, dan oleh karena hal itu tidak sejalan dengan UU pokok perbankan yang berlaku, yaitu UU No. 14 Tahun 1967. Konsep bank syariah dari segi politis juga dianggap berkonotasi ideologis, merupakan bagian atau berkaitan dengan konsep negara Islam, oleh karena itu tidak dikehendaki pemerintah. Dan akhirnya setelah melewati hambatan akhirnya Bank Syariah ini didirikan oleh Majelis Ulama Indonesia pada 18-20 Agustus 1990.

Dalam perkembangan selanjutnya dari kehadiran Bank Syariah di Indonesia sangat mengembirakan. Disamping Bank Muamalat Indonesia saat ini juga telah lahir Bank syariah milik pemerintah seperti Bank Syariah Mandiri. Kemudian berikutnya berdiri Bank Syariah sebagai cabang dari bank konvensional yang sudah ada seperti Bank BNI, Bank BRI dan lain-lain. Dengan latar belakang adanya suatu keyakinan dalam agama Islam yang merupakan suatu alternatif atas perbankan dengan kekhususannya pada prinsip syariah.

\section{b. Dasar Hukum Bank Syariah}

Berdirinya Bank Syariah di Indonesia tentunya memiliki landasan atau dasar hukum yang melindungi dan menjadi dasar menjalankan segala aktivitas perekonomian yang meliputi kegiatan perbankan. Dalam berjalannya segala aktivitas perbankan, bank syariah memiliki dua dasar hukum berdasarkan peraturan negara dan berdasarkan AlQur"an dan hukum islam yang lainnya.

a) Berdasarkan Hukum Islam

Dasar hukum utama yang menjadi landasan berdirinya bank syariah antara lain Q.S An-Nisa 29: 


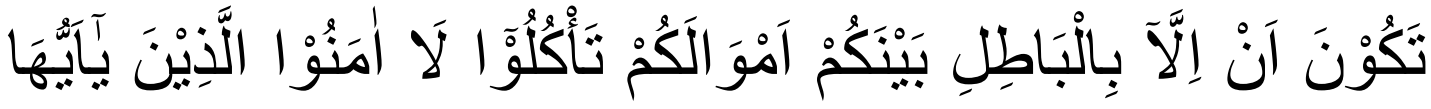

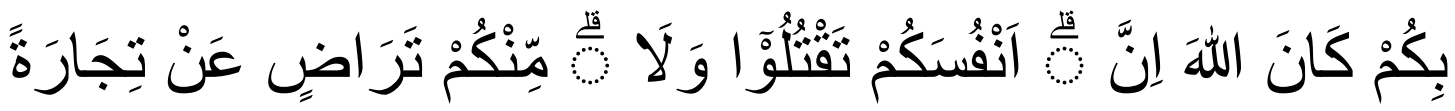 رَحِيْمَا}

Artinya:

"Wahai orang-orang yang beriman! Janganlah kamu saling memakan harta sesamamu dengan jalan yang batil (tidak benar), kecuali dalam perdagangan yang berlaku atas dasar suka sama suka di antara kamu. Dan janganlah kamu membunuh dirimu. Sungguh, Allah Maha Penyayang kepadamu."

Dalam artian ini bisa ditafsirkan bahwa bank syariah dalam melaksanakan tugasnya tidak boleh menyeleweng dari ajaran Islam (batil) namun harus selalu tolong menolong demi menciptakan suatu kesejahteraan. Kita tahu banyak sekali tindakan-tindakan ekonomi yang tidak sesuai dengan ajaran Islam hal ini terjadi karena beberapa pihak tidak tahan dengan godaan uang serta mungkin mereka memiliki tekanan baik kekurangan dalam hal ekonomi atau yang lain, maka bank syariah harus membentengi mereka untuk tidak berbuat sesuatau yang menyeleweng dari Islam.

Ayat selanjutnya yang menjadi landasan hukum Bank Syariah terdapat dalam Q.S Al-Baqarah 283:

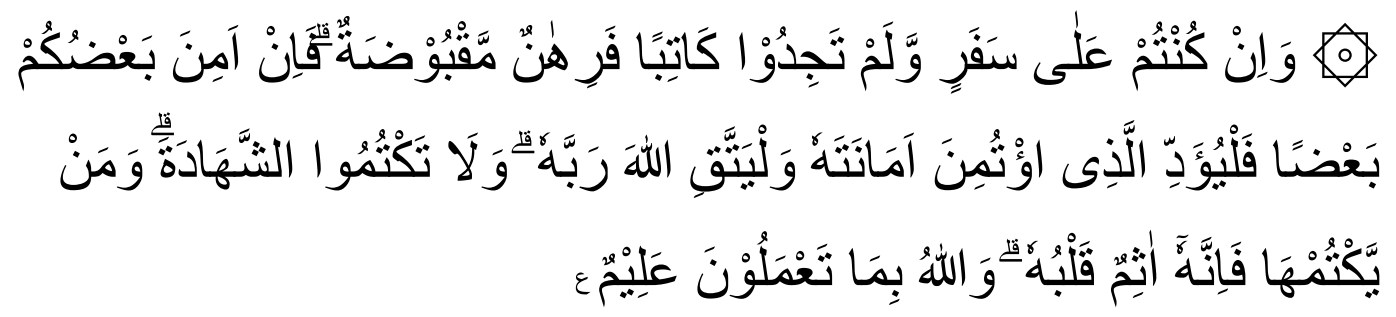

Artinya:

"Jika kamu dalam perjalanan (dan bermu'amalah tidak secara tunai) sedang kamu tidak memperoleh seorang penulis, maka hendaklah ada barang tanggungan yang dipegang (oleh yang berpiutang). Akan tetapi jika sebagian kamu mempercayai sebagian yang lain, maka hendaklah yang dipercayai itu menunaikan amanatnya (hutangnya) dan hendaklah ia bertakwa kepada Allah Tuhannya; dan janganlah kamu (para saksi) menyembunyikan 
persaksian. Dan barangsiapa yang menyembunyikannya, maka sesungguhnya ia adalah orang yang berdosa hatinya; dan Allah Maha Mengetahui apa yang kamu kerjakan.”

Dari ayat ini bisa diambil salah satu poin penting yakni menyampaikan amanat. Dalam bank syariah baik pihak bank maupun nasabah harus menjaga yang telah disepakati dalam akad sebelumnya hal ini bertujuan untuk menjaga kepercayaan dan tetap berkegiatan ekonomi tanpa kecurangan atau kebohongan sedikitpun. Bisa di bilang harus terbuka dan transparan.

Meski Bank Syariah berlandaskan Al-Qurean, Sunnah dan Ijtihad sebagai pelengkap, namun bank ini tidak menutup diri untuk mendasarkan kegiatan atau aktivitasnya berdasarkan atau sesuai peraturan perundang-undangan yang telah ditetapkan oleh pemerintah, hal ini terjadi karena Indonesia merupakan negara kesatuan dan berlandaskan atas Pancasila tentu tidak etis jika hukum tertinggi di negara ini yakni Undang-Undang maupun pemerintah tidak dijadikan sebuah landasan hukum.

b) Berdasarkan Hukum Nasional

Dalam Undang-undnag ini bank syariah diposisikan sebagai bank umum serta bank pengkreditan rakyat, dimana pemerintahan telah memberikan izin atas keberadaan bank syariah untuk melakukan segala tindakan atau kegiatan perbankan layaknya seperti bank konvensioal. Landasan hukum yang melindungi Bank Syariah di Indonesia, ada beberapa peraturan yang membahas tentang Bank syariah, yaitu:

a. UU No. 10 Tahun 1998

Undang-undang ini berisikan tentang penyempurnaan dan penjelasan dari UndangUndang no.7 Tahun 1992, yakni penjelasan tentang bagaimana bank syariah sebagai bank umum dan bank pengkereditan rkayat khususnya berada di pasal 6 serta berisi juga tentang penjabaran dari prinsip syariah.

b. UU No. 23 Tahun 2003

Dalam undang-undang ini berisi tentang perlindungan dari keberadaan bank syariah, dimana perlindungan terebut bebentuk penugasan kepada Bank Indonesia untuk mempersiapkan segala bentuk perangkat aturan serta fasilitas-fasilitas yang mampu 
menunjang segala bentuk kegiatan yang imbasnya akan mendukung kelancaran dan keefektifan jalannya operasional bank syariah.

c. UU No. 21 Tahun 2008

Undang-undang ini yang lebih spesifik diantara peraturan yang lainnya, dalam undang-undang ini sebenarnya muncul ketika memang di Indonesia perkembangan bank syariah semakin pesat untuk itulah ketentuan dan peraturan yang ada dalam unang-undang ini sangan lengkap. Dalam bab 1 pasal 1 bahakan sudah disebutkan secara jelas tentang perbedaan bank konvensional dan bank syariah dimana diberikan beberapa pengertian serta jenis-jenis yang dimiliki oleh masing-masing bank. Tidak hanya itu dalam undnag-undang ini juga dijelaskan bahwasanya dalam usaha menjalankan fungsinya bank syariah melakukann penghimpunan dana dari nasabah dan akan menyalurkan pembiayaan tersebut berdasarkan akad yang telah diatur dalam ekonomi Islam seperti mudharabah, wadiah, musyarakah (Dian, 2007) .

d. UUD 1945 Pasal 33

Hukum pertama yang menjadi asas kegiatan perbankan baik konvensional maupun syariah harus memenuhi beberapa kriteria yang telah ditetapkan dalam undang-undang dasar 1945 pasal 33, antara lain:

1) Segala bentuk perekonomian disusun sebagai sebuah usaha bersama berdasarkan atas asas kekeluargaan.

2) Semua cabang produksi yang vital atau penting bagi negara serta menjadi hajat hidup orang banyak dikuasai oleh negara.

e. Peraturan Bank Indonesia No. 9/19/PBI/2007 tentang Pelaksanaan Prinsip Syariah Dalam Kegiatan Penghimpunan Dana dan Penyaluran Dana serta Pelayanan Jasa Bank Syariah, yang telah diubah dalam Peraturan BI No. 10/16/PBI/2008 Tahun 2008.

\section{Kegiatan Usaha Bank Syariah}

Bank Syariah merupakan salah satu aset dalam perbankan Indonesia yakni sebuah lembaga keuangan yang segala ativitasnya didasrkan pada nilai-nilai atau hukum Islam. Setiap lembaga pasti memiliki kegiatan, baik yang terprogram masuk dalam undangundang maupun independen. Begitu juga dengan bank syariah ini memiliki beberapa bentuk kegiatan usaha yang terhimpun dalam Undang-Undang Republik Indonesia No. 
21 tahun 2008, tepatnya pada pasal 19. Dalam pasal 19 ini dijelaskan bahwasanya kegiatan usaha bank syariah meliputi 3 pokok kegiatan yakni penghimpun dana masyarakat, penyaluran dana langsung maupun tidak langsung, dan jasa layanan. Dari tiga pokok tersebut akan di kembangkan oleh beberapa kegiatan antara lain:

a) Penghimpun Dana Masyarakat

Dalam kegiatan ini, Bank Syariah mengadakan beberapa program atau kegiatan yang meliputi:

1. Menghimpun dana dalam bentuk simpanan berupa giro, tabungan maupun dalam bentuk lainnya. Segala bentuk penyimpanan dana ini harus disamakam dan disesuaikan dengan nilai-nilai keIslaman tepatnya harus berdasarkan prinsip-prinsip ekonomi syariah yakni akad wadiah yang dimaksud dengan wadiah adalah sebuah titipan yang dilakukan oleh satu orang kepihak yang lainnya baik dalam lingkup individu maupun badan hukum dan harus dijaga serta dikembalikan kepada pihak yang melakukan titipan.

2. Melakukan penghimpunan dana dalam bentuk investasi baik dalam bentuk tabungan, deposito, giro atau dalam bentuk yang lainnya yang penting didasarkan pada salah satu akad ekonomi syariah yakni akad mudharabah yang dimaksud dengan akad mudharabah adalah sebuah kesepakatan kerjasama antara dua pihak, dimana pihak pertama menjadi penyedia modal tersebut.

b) Penyaluran Dana

Kegiatan usaha penyaluran dana ini fokus pada tiga aspek penting yakni jual beli, sewa dan investasi.

1) Jual Beli

Jual beli yang dilakukan dalam bentuk syariah ini berbeda dengan jual beli pada umumnya, dimana kegiatan jual beli ini bisa di laksanakan dengan 3 skema, yakni skema salam, murabahah dan isthsna. Dalam jual beli murabahah penjual memperoleh sebuah keuntungan dari kesepakatan bersama antara pembeli dan penjual. Jika di perbankan syariah yang menjadi pembeli adalah nasabah. Sedangkan untuk skema salam pelunasan pembayaran harus dilaksanakan sebelum barang atau produk sampai pada tangan pembeli. Dan skema istishna merupakan jual beli dimana penjual 
melaksanakan apa yang diminta oleh pembeli bisa dibilang pembeli merupakan salah satu fokus utama bagi penjual.

2) Sewa

Sewa disini memiliki dua skema yakni skema ijarah dan muntahiyah bittamlik. Skema ijarah adalah penyewaan suatu barang atau produk dalam waktu tertentu tanpa adanya perpindahan kekuasaan atau kepemilikan. Sedangkan sewa dengan skema mutahiyah adalah penyewaan yang terdiri dari kombinasi sewa dan jual beli, di mana barang atau apapun yang disewakan akan dijual pada akhir periode sewanya.

3) Investasi

Investasi dalam bank syariah bisa dilakukan denga dua skema akad, yakni mudharabah dan musyarakah. Dimana jika mudharabah pengelola dana memiliki hak dan kewenangan untuk memanfaatkanya, namun jika musyarakah pihak pengelola dibatasi dengan pengawasan dari pemilik modal.

Pada dasarnya Bank Syariah memiliki hak dan wewenang untuk melaksanakan program-program atau kegiatan perekonomian atau perbankan, namun harus tetap mengutamakan nilai-nilai Islam serta prinsip-prinsip yang dipegang oleh Bank Syariah. Inilah beberapa kegiatan usaha bank syariah yang telah diatur dalam UU RI No. 21 tahun 2008 pasal 19 (Dian, 2007).

\section{Prinsip-Prinsip Bank Syariah}

Prinsip dalam kegiatan usaha bank syariah adalah aturan yang berdasarkan hukum Islam antara bank dan pihak lain untuk penyimpanan dana dan/atau pembiayaan kegiatan usaha, atau kegiatan lainnya yang dinyatakan sesuai dengan syariah. Kegiatan usaha dengan prinsip syariah, antara lain: Bank Syariah memiliki 5 konsep utama yang menjadi dasar operasional, yaitu:

1) Prinsip Simpanan Murni (al-wadie $\left.{ }^{e} a h\right)$

Prinsip al-wadieeah sering juga disebut titipan merupakan prinsip yang hanya digunakan bank untuk produk simpanan. Simpanan al-wadiceah tidak mendapatkan keuntungan bagi hasil ataupun, al-wadieeah hanya menerapkan bonus dari Bank.

2) Bagi Hasil 
Konsep ini meliputi tata cara pembagian hasil usaha antara shahibul maal (penyedia dana) dengan mudharib (pengelola dana). Nisbah bagi hasil ini dapat terjadi antara bank dengan penyimpanan dana, maupun antara bank dengan nasabah penerima dana. Prinsip ini memiliki bentuk produk yaitu Mudharabah dan Musyarakah. Lebih jauh prinsip mudharabah dapat dipergunakan sebagai dasar baik untuk produk pendanaan (tabungan dan deposito) maupun pembiayaan, sedangkan musyarakah lebih banyak untuk pembiayaan.

\section{3) Prinsip Jual Beli (al-Tijarah)}

Prinsip ini merupakan suatu sistem yang menjelaskan bagaimana penerapan konsep jual beli, dimana bank akan membeli terlebih dahulu barang yang dibutuhkan atau mengangkat nasabah sebagai agen bank melakukan pembelian barang atas nama bank, kemudian bank menjual barang tersebut kepada nasabah dengan harga sejumlah harga beli di tambah keuntungan (margin).

\section{4) Prinsip Sewa (al-Ijarah)}

Prinsip ini terbagi dua jenis : (1) ijarah, sewa murni, seperti halnya penyewaan traktor dan alat-alat produk lainnya (operating lease). Dalam teknis perbankan, bank dapat membeli equitment yang dibutuhkan nasabah kemudian dan menyewakan dalam waktu dan hanya yang telah disepakati kepada nasabah. (2) Baieeal takjiri atau Ijarah Al Muntahiya Bi Tamlik merupakan penggabungan sewa dan beli, dimana si penyewa mempunyai hak untuk memiliki barang pada akhir masa sewa (finansial lease).

5) Prinsip jasa/fee (al-Ajr walumullah)

Bentuk produk yang berdasarkan prinsip ini antara lain Bank Garansi, Kliring, Inkaso, Jasa, Transfer, dll. Secara syariah prinsip ini didasarkan pada konsep al ajr wal umulah.

\section{Sistem Bagi Hasil}

\section{a. Pengertian Bagi Hasil}

Menurut Muhammad (2004) Bagi hasil menurut terminologi asing (inggris) dikenal dengan Profit sharing. Profit sharing dalam kamus ekonomi diartikan pembagian laba. Secara definitif profit sharing diartikan sebagai distribusi beberapa bagian laba pada para pegawai dari suatu perusahaan. Lebih lanjut dikatakan, hal itu dapat berbentuk suatu bonus 
uang tunai tahunan yang didasarkan pada laba yang diperoleh pada tahun-tahun sebelumnya atau dapat berbentuk pembayaran mingguan atau bulanan.

Prinsip bagi hasil (profit sharing) merupakan karakteristik umum dan landasan bagi operasional bank islam secara keseluruhan. Prinsip bagi hasil dalam simpanan/tabungan tersebut menetapkan tingkat keuntungan/pendapatan bagi tiap-tiap pihak. Pembagian keuntungan dilakukan melalui tingkat perbandingan rasio, bukan ditetapkan dalam jumlah yang pasti (Hakim, 2012).

Bagi Hasil adalah suatu sistem pengolahan dana dalam perekonomian Islam yakni pembagian hasil usaha antara pemilik modal (Shahibul Mal) dan pengelola (Mudharib). Proses penentuan tingkat bagi hasil diperlukan kesepakatan kedua belah pihak, yang terungkap dalam nisbah bagi hasil (Rivai dan Arifin, 2010).

b. Konsep Bagi Hasil

Bagi hasil adalah pembagian atas hasil usaha yang telah dilakukan oleh pihak-pihak yang melakukan perjanjian yaitu pihak nasabah dan pihak Bank Syariah. Dalam hal terdapat dua pihak yang melakukan perjanjian usaha, maka hasil atas usaha yang dilakukan oleh kedua pihak atau salah satu pihak, akan dibagi sesuai dengan porsi masing-masing pihak yang melakukan akad perjajian. Pembagian hasil usaha dalam perbankan syariah ditetapkan dengan mengunakan nisbah. Nisbah yaitu persentase yang disetujui oleh kedua belah pihak dalam menentukan bagi hasil atas usaha yang dikerjasamakan (Ismail, 2011).

Jarang sekali ditemukan konsep usaha yang terus berjalan (running business) ketika mitra usaha bisa datang dan pergi setiap saat bisa mempengaruhi jalannya usaha. Hal ini disebabkan buku-buku fiqih Islam ditulis pada waktu usaha tidak sebesar dan serumit usaha zaman sekarang, sehingga konsep "running business" tidak mendapat perhatian (Ascarya, 2012).

Hal tersebut, tidak berarti bahwa konsep bagi hasil tidak dapat diterapkan untuk pembiayaan suatu usaha yang sedang berjalan. Konsep bagi hasil berlandaskan pada beberapa prinsip dasar. Selama prinsip - prinsip dasar ini dipenuhi, detail dari aplikasinya akan bervariasi dari waktu ke waktu. Beberapa prinsip dasar konsep bagi hasil yang ditemukan oleh Usmani (1999) adalah sebagai berikut:

- Bagi hasil tidak berarti meminjamkan uang, tetapi merupakan partisipasi dalam usaha. 
- Investor atau pemilik dana harus ikut menanggung resiko kerugian usaha sebatas proporsi pembiayaanya.

- Para mitra usaha bebas menentukan, dengan persetujuan bersama, rasio keuntungan untuk masing-masing pihak, yang dapat berbeda dari rasio pembiayaan yang disertakan.

- Kerugian yang di tanggung oleh masing-masing pihak harus sama dengan proporsi investasi mereka.

Dapat dipahami bahwa Bagi hasil adalah pembagian atas hasil usaha yang telah dilakukan oleh pihak-pihak yang melakukan perjanjian yaitu pihak nasabah dan pihak Bank Syariah, dalam hal ini terdapat dua pihak yang melakukan perjanjian usaha, maka hasil atas usaha yang dilakukan akan dibagi sesuai dengan nisbah yang disetujui oleh kedua belah pihak.

c. Metode Perhitungan Bagi Hasil

Dapat dipahami bahwa Bagi hasil adalah pembagian atas hasil usaha yang telah dilakukan oleh pihak-pihak yang melakukan perjanjian yaitu pihak nasabah dan pihak Bank Syariah, dalam hal ini terdapat dua pihak yang melakukan perjanjian usaha, maka hasil atas usaha yang dilakukan akan dibagi sesuai dengan nisbah yang disetujui oleh kedua belah pihak.

a) Bagi Hasil dengan Menggunakan Revenue Sharing

1. Yang dibagikan adalah pendapatan.

2. Shahibul mal menanggung kerugian: usaha dilikuidasi, jumlah aktiva lebih kecil daripada kewajiban

Dasar perhitungan bagi hasil dengan menggunakan revenue sharing adalah perhitungan bagi hasil yang didasarkan atas penjualan dan/atau pendapatan kotor atas usaha sebelum dikurangi dengan biaya.9 Bagi pendapatan (Revenue Sharing) adalah bagi hasil yang dihitung dari total pendapatan pengelolaan dana. Jadi metode ini dihitung dari pendapatan kantor sebelum dikurangi dengan biaya.

b) Bagi Hasil dengan Menggunakan Profit/Loss Sharing

1. Yang dibagikan adalah keuntungan (profit). 
2. Kerugian bukan kelalaian mudharib di tanggung oleh shahibul maal.

Dasar perhitungan bagi hasil dengan menggunakan profit/loss sharing merupakan bagi hasil yang dihitung dari laba/rugi usaha. Kedua pihak, Bank Syariah maupun nasabah akan memperoleh keuntungan atas hasil usaha mudharib dan ikut menanggung kerugian bila usahanya menanggung kerugian. Jadi, Profit/Loss Sharing adalah bagi hasil yang dihitung dari pendapatan setelah dikurangi biaya pengelolaan dana.

\section{Pembiayaan Mudharabah}

a. Pengertian Pembiayaan Mudharabah

Secara luas pembiayaan berarti financing atau pembelanjaan, yaitu pendanaan yang dikeluarkan untuk mendukung investasi yang telah direncanakan, baik dilakukan sendiri maupun dijalankan oleh orang lain. Dalam arti sempit, pembiayaan dipakai untuk mendefinisikan pendanaan yang dilakukan oleh lembaga pembiayaan, seperti bank syariah kepada nasabah (Arif, 2012). Menurut Kusumawati dalam Daga (2021) Pembiayaan adalah pendanaan yang dikeluarkan oleh lembaga pembiaayaan seperti Bank syariah kepada nasabah. Jadi pembiayaan adalah sebuah fasilitas berupa produk perbankan syariah yang memberikan pinjaman bagi debitur atau calon anggota yang kekurangan dana untuk sebuah usaha dimana pihak debitur diwajibkan memberikan angsuran setiap jangka waktu tertentu dengan bagi hasil yang telah disepakati diawal persetujuan kedua belah pihak.

Mudharabah berasal dari kata darb, berarti memukul atau berjalan. Maksud dari kata memukul dan berjalan dalam hal ini adalah proses seseorang memukulkan kakinya dalam melakukan usaha (Antonio, 2001). Pembiayaan mudharabah adalah akad perjanjian antara dua belah pihak atau lebih untuk melakukan kerjasama usaha. Satu pihak akan menempatkan modal sebesar 100\% yang disebut dengan shahibul mal, dan pihak lainnya sebagai pengelola usaha, disebut dengan mudharib. Bagi hasil dari kerjasama yang diusahakan dihitung sesuai dengan nisbah yang disepakati antara pihak-pihak yang bekerjasama.

Secara teknis, akad mudharabah adalah akad kerjasama antara dua belah pihak, yang mana pihak pertama (shahibul mal) menyediakan seluruh modalnya, sedangkan pihak lain yang menjadi pengelola (mudharib). Keuntungan usaha secara mudharabah dibagi menurut kesepakatan yang dituangkan dalam kontrak, sedangkan apabila mengalami kerugian akan 
ditanggung oleh pemilik modal selama kerugian tersebut bukan merupakan kelalaian dari si pengelola. Apabila kelalaian tersebut diakibatkan oleh kecurangan atau kelalaian si pengelola, maka harus bertanggung jawab atas kelalaian tersebut.

Dari kesimpulan tersebut dapat diartikan bahwa pembiayaan mudharabah merupakan transaksi penanaman modal dari pemilik dana kepada pengelola dana untuk melakukan kegiatan usaha tertentu berdasarkan prinsip syariah, dengan pembagian hasil usaha antara kedua belah pihak berdasarkan nisbah yang telah disepakati sebelumnya dan apabila terdapat kerugian maka kerugian itu harus ditanggung bersama selama kesalahan bukan berasal dari pihak pengeloa (mudharib).

b. Rukun dan Syarat Mudharabah

Akad mudharabah harus memenuhi rukun dan syaratnya. Adapun rukun dan syarat mudharabah yaitu:

a) Rukun mudharabah ada lima, yaitu:

1. Pihak yang melakukan akad (shahibul mal dan mudharib) harus cakap hukum.

2. Modal yang diberikan oleh shahibul mal yaitu sejumlah uang atau aset untuk tujuan usaha.

3. Pernyataan ijab kabul, dituangkan secara tertulis yang menyangkut semua ketentuan yang disepakati dalam akad.

4. Keuntungan mudharabah adalah jumlah yang didapat sebagai kelebihan dari modal yang telah diserahkan oleh shahibul mal kepada mudharib.

5. Kegiatan usaha mudharib sebagai pertimbangan modal yang disediakan oleh shahibul mal, akan tetapi harus mempertimbangkan sebagai berikut:

1. Kegiatan usaha adalah hak mudharib, tanpa campur tangan shahibul mal, kecuali untuk pengawasan.

2. Penyedia dana tidak boleh mempersempit tindakan pengelola yang mengakibatkan tidak tercapainya tujuan mudharabah, yaitu memperoleh keuntungan.

3. Pengelola tidak boleh menyalahi hukum syariah, dan harus mematuhi semua perjanjian (Ali, 2010).

b) Syarat-syarat mudharabah yang melekat pada rukunnya adalah sebagai berikut: 
1.Modal atau barang yang disediakan itu berbentuk uang tunai. Apabila barang itu berbentuk emas atau perak batangan, mas hiasan atau barang lainnya, mudharabah tersebut batal.

2.Bagi orang yang melakukan akad disyaratkan mampu melakukan tasharruf, maka dibatalkan akad anak-anak yang masih kecil, orang gila, dan orang-orang yang berada di bawah pengampunan.

3.Modal harus diketahui dengan jelas agar mudah dibedakan antara modal yang diperdagangkan dengan laba atau keuntungan dan perdagangan tersebut yang akan dibagikan kepada dua belah pihak sesuai dengan perjanjian yang telah disepakati.

4. Melafadzkan ijab dari pemilik modal, misalkan aku serahkan uang ini kepadamu untuk dagang jika ada keuntungan akan dibagi dua dan kabul untuk pengelola.

5.Mudharabah bersifat mutlak, pemilik modal tidak menikat pengelola harta untuk berdagang di negara tertentu, pada waktu-waktu tertentu, sementara diwaktu lain tidak karena persyaratan yang mengikat sering menyimpang dari tujuan akad mudharabah yaitu keuntungan (Suhendi, 2010).

6.Keuntungan harus diperuntukkan bagi kedua belah pihak dan tidak boleh di persyaratkan hanya untuk satu pihak.

7. Bagian keuntungan proporsional bagi setiap pihak dan harus diketahui serta dinyatakan pada waktu kontrak disepakati dalam bentuk persentase/ nisbah.

8. Penyedia dana menanggung semua kerugian atas usaha yang dikelola oleh mudharib , dan pengelola tidak boleh menanggung kerugian apapun. Kecuali terhadap kerugian yang diakibatkan oleh kesalahan berupa kesengajaan, kelalaian, dan pelanggaran kesepakatan.

c. Jenis - jenis Mudharabah

Pada prinsipnya, mudharabah sifatnya mutlak dimana shahibul mal tidak menetapkan syarat-syarat tertentu kepada si mudharib. Namun demikian dalam praktik perbankan syariah modern kini dikenal dengan dua jenis bentuk pembiayaan mudharabah, yaitu:

a) Mudharabah Muthlaqah, yang dimaksud dengan Mudharabah Muthlaqah yaitu pemilik dana memberikan keleluasaan penuh kepada pengelola untuk menggunakan dana tersebut dalam usaha yang dianggapnya baik dan menguntungkan. Pengelola bertanggung jawab untuk mengelola usaha sesuai dengan praktik kebiasaan usaha yang 
sehat (uruf) (Karim, 2010). Jadi, yang dimaksud pembiayaan mudharabah mutlaqoh adalah bentuk kerja sama dimana shohibul maal tidak membatasi mudharib dalam mengelola modalnya. Mudharib mempunyai keleluasan untuk menggunakan dan mengembangkan modal tersebut.

b) Mudharabah Muqayyadah, yang dimaksud dengan Mudharabah Muqayyadah yaitu pemilik dana menentukan syarat dan pembatasan kepada pengelola dalam penggunaan dana tersebut dalam jangka waktu, tempat, jenis usaha dan sebagainya. Pengelola menggunakan modal tersebut dengan tujuan yang dinyatakan secara khusus, yaitu untuk menghasilkan keuntungan. Jadi, dalam hal ini mudharib dibatasi dalam penggunaan dananya sejak awal disepakati, bahwa dana tersebut hanya dapat dialokasikan untuk pembiayaan proyek tertentu. Atas dasar akad ini, mudharib tidak dapat melakukan penyimpangan dalam penggunaannya. kesepakatan besarnya bagi hasil dilakukan dimuka dengan nisbah tertentu.

d. Ketentuan dalam Pembiayaan Mudharabah

Ada beberapa ketentuan yang harus dimengerti dan dipahami oleh masing-masing pihak yang melakukan akad mudharabah. Berikut beberapa ketentuan pembiayaan mudharabah, sebagai berikut:

1. Pembiayaan mudharabah digunakan untuk usaha yang bersifat produktif. Menurut jenis penggunaanya Pembiayaan mudharabah diberikan untuk pembiayaan investasi dan modal kerja.

2. Shahibul mal (Bank Syariah/Unit Usaha Syariah/Bank Pembiayaan Rakyat Syariah) membiayaai 100\% suatu proyek usaha, dan mudharabah (nasabah pengelola usaha) bertindak sebagai pengelola proyek usaha.

3. Mudharib boleh melakukan berbagai macam usaha sesuai dengan akad yang telah disepakati bersama antara Bank Syariah dan nasabah. Bank Syariah tidak ikut serta dalam pengelolaan perusahaan, akan tetapi memiliki hak untuk melakukan pembinaan dan pengawasan terhadap kinerja mudharib.

4. Jumlah modal yang diserahkan kepada nasabah selaku pengelola modal, harus diserahkan tunai, dapat berupa uang atau barang yang dinyatakan nilainya dalam satuan uang. Apabila modal diserahkan secara bertahap, harus jelas tahapannya dan disepakati bersama (Sumar'in, 2010). 
5. Hasil dari pengelolaan modal pembiayaan mudharabah dapat diperhitungkan dengan dua cara yaitu hasil usaha dibagi sesuai dengan persetujuan dalam akad, pada setiap bulan atau waktu yang disepakati. Bank selaku pemilik modal menanggung seluruh kerugian kecuali akibat kelalaian dan penyimpangan pihak nasabah, seperti penyelewengan, kecurangan dan penyalahgunaan data.

e. Penerapan Mudharabah Dalam Perbankan Syariah

Sejauh ini skema mudharabah yang kita kenal adalah skema yang berlaku antara kedua belah pihak saja secara langsung, yakni shahib almal berhubungan langsung dengan mudharib. Skema ini adalah skema standar yang dapat dijumpai pada kitab-kitab klasik fiqih Islam. Dan inilah sesungguhnya praktik mudharabah yang dilakukan oleh nabi dan para sahabat umat muslim sesudahnya. Dalam kasus ini investasi yang terjadi adalah investasi langsung antara shahib al-mal dengan mudharib. Dalam hal ini peran bank sebagai lembaga perantara tidak ada.

Modus mudharabah seperti itu tidak efisien lagi dan kecil kemungkinan untuk dapat diterapkan oleh bank, karena beberapa hal:

1) Sistem kerja pada bank adalah investasi berkelompok, dimana mereka tidak saling mengenal. Jadi kecil sekali kemungkinan terjadi hubungan yang langsung dan personal.

2) Banyak investasi sekarang ini membutuhkan dana dalam jumlah besar sehingga diperlukan puluhan bahkan ratusan ribu shahibul maal untuk sama-sama menjadi penyandang dana untuk satu proyek tertentu.

3) Lemah disiplin terhadap ajaran Islam menyebabkan sulitnya bank untuk memperoleh jaminan keamanan atas modal yang disalurkan (Karim, 2004).

Mengatasi hal di atas, khususnya masalah pertama dan kedua, maka mudharabah yang melibatkan pihak tambahan. Satu pihak ini diperankan oleh Bank Syariah sebagai perantara yang mempertemukan shahib al-mal dengan mudharib. Jadi terjadi evolusi dari konsep direct financing menjadi indirect financing.

Indirect financing, bank menerima dana dana dari shahib al-mal dalam bentuk dana pihak ketiga (DP-3) sebagai sumber dananya. Dana dana ini dapat berbentuk tabungan atau simpanan deposito dengan jangka waktu yang bervariasi. Selanjutnya dana-dana yang sudah terkumpul disalurkan kembali oleh bank ke dalam bentuk pembiayaan- 
pembiayaan yang menghasilkan. Keuntungan dari penyaluran pembiayaan akan dibagihasilkan antara bank dengan pemilik DP-3.

Kontrak mudharabah dalam bank Islam kebanyakan digunakan untuk tujuan perdagangan jangka pendek dan jenis usaha tertentu. Dalam hal ini, posisi mudharib bertindak sebagai nasabah bank Islam untuk meminta pembiayaan usaha berdasarkan kontrak mudharabah. Mudharib mendapat dukungan dana dari bank, yang dengan dana tersebut mudharib dapat memulai menjalankan usahanya dengan membelanjakannya dalam bentuk barang dagangan untuk dijual kepada pembeli, dengan tujuan agar memperoleh keuntungan (profit). Sebelum pembiayaan tersebut disetujui, mudharib memberikan penjelasan terlebih dahulu kepada bank mengenai seluk beluk usaha yang berkaitan dengan barang, sumber pembelanjaan maupun seluruh biaya yang dikeluarkan untuk memperoleh barang tersebut. Mudharib mengajukan sejumlah persyaratan finansial yang membuat beberapa hal menyangkut ketentuan harga penjualan, arus pembayaran, dan tingkat keuntungan yang akan diperoleh. Persyaratan tersebut akan di pelajari oleh pihak bank sebelum memutuskan menyetujui pembiayaan usaha tersebut. Bank umumnya akan menyetujui membiayai usaha tersebut jika tingkat keuntungan yang di harapkan cukup menjanjikan (Saeed, 2008).

Akad mudharabah, pemilik dana tidak boleh mensyaratkan sejumlah tertentu untuk bagiannya karena dapat disamakan dengan riba yaitu meminta kelebihan atau imbalan tanpa ada faktor penyeimbang atau iwad yang diperbolehkan syariah. Dalam mudharabah, pembagian keuntungan harus dalam bentuk persentase/ nisbah, misalnya $70: 30,70 \%$ untuk pengelola dana dan 30\% untuk pemilik dana. Sehingga keuntungan yang diterima sesuai dengan laba yang dihasilkan (Nurhayati, 2013).

Keuntungan yang dibagikanpun tidak boleh menggunakan nilai proyeksi akan tetapi harus menggunakan nilai realisasi keuntungan, yang mengacu pada laporan hasil usaha yang secara periodik disusun oleh pengelola dana dan diserahkan pada pemilik dana. Pada prinsipnya dalam mudharabah tidak boleh ada jaminan atas modal, namun demikian agar agar pengelola dana tidak melakukan penyimpangan, pemilik dana dapat meminta jaminan dari pengelola dana atau pihak ketiga.

\section{Penelitian Terdahulu}


a. Suryanti (2019) dengan judul penelitian "PENERAPAN SISTEM BAGI HASIL PEMBIAYAAN MUDHARABAH PADA PT. BPRS AMAN SYARIAH LAMPUNG TIMUR". Hasil penelitian ini menunjukkan bahwa penerapan sistem bagi hasil pembiayaan mudharabah yang dilakukan PT. BPRS Aman Syariah Lampung Timur yaitu menggunakan metode revenue sharing karena sesuai dengan anjuran Fatwa DSN MUI bahwa metode revenue sharing lebih tepat digunakan dalam pembiayaan mudharabah. Untuk keuntungan yang dibagikan bank tidak berdasarkan proyeksi diawal perjanjian. Keuntungan yang didapatkan dihitung kembali sesuai realisasi keuntungan yang didapatkan. Jadi penerapan sistem bagi hasil yang diterapkan PT. BPRS Aman Syariah Lampung Timur sudah sesuai dengan prinsip Islam. Dimana pembagian keuntungan tidak boleh berdasarkan proyeksi di awal akad.

b. Abdullah (2017) dengan judul penelitian "PENERAPAN SISTEM BAGI HASIL PADA PEMBIAYAAN MUDHARABAH DI BANK BNI SYARIAH CABANG MAKASSAR". Hasil penelitian ini menyatakan bahwa mekanisme pembiayaan mudharabah pada PT. Bank BNI Syariah juga telah mengikuti aturan Fatwa DSN karena ada DPS yang selalu memastikan Bank BNI Syariah telah menjalakan sistemnya sesuai dengan aturan. Dan untuk mengenai pelaksanaan sistem bagi hasilnya Bank BNI Syariah mengenakan bagi hasil berdasarkan metode bagi hasil usaha (gross profit margin) untuk rasio pembagian labanya maka pihak Bank BNI Syariah melihat dari jangka waktu pembiayaan pihak Bank tidak menyebutkan berapa persisnya antara Bank dan Nasabah melainkan Bank melakukan negosiasi.

\section{METODELOGI PELITIAN}

\section{A. LOKASI DAN WAKTU PENELITIAN}

Penelitian ini dilakukan di PT BNI Syariah cabang Makassar yang berlokasi di Jl. Pajonga Dg. Ngalle No.140, Mario, Mariso, Kota Makassar, dengan waktu penelitian selama kurang lebih 1 (satu) bulan.

\section{B. JENIS DAN SUMBER DATA}


1. Jenis Data

Jenis data yang digunakan dalam penelitian ini berupa penelitian data kualitatif, yaitu data lapangan (field research). penelitian lapangan yaitu penelitian yang dilakukan dilapangan atau di lokasi penelitian, suatu tempat yang dipilih sebagai lokasi untuk menyelidiki gejala objektif sebagai terjadi di PT Bank BNI cabang Makassar.

2. Sumber Data

1. Data primer yaitu data yang diperoleh langsung dari sumbernya.

2. Data sekunder yaitu data yang diperoleh dari berbagai sumber, seperti buku, majalah jurnal, karya ilmiah, internet, dan berbagai sumber lainnya.

\section{TEKNIK PENGAMBILAN DATA}

Adapun teknik pengambilan data dalam penelitian ini adalah:

\section{Wawancara}

Menurut Bungin (2013) metode wawancara adalah proses memperoleh keterangan untuk tujuan penelitian dengan cara tanya jawab sambil bertatap muka antara pewawancara dengan responden atau orang yang diwawancarai, dengan atau tanpa menggunakan pedoman (guide) wawancara. Pewawancara mengajukan pertanyaan kepada beberapa pihak responden yang berkompeten untuk memberikan informasi.

\section{Dokumentasi}

Metode dokumentansi adalah teknik pengumpulan data yang dilakukan untuk mencari data yang diteliti. Teknik ini digunakan untuk memperoleh informasi serta keterangan mengenai daerah lokasi, sejarah, visi dan misi serta menyelidiki bendabenda tertulis seperti buku-buku, peraturan-peraturan dalam bagi hasil mudharabah, catatan harian, dan laporan semester dan tahunan pembiayaan mudharabah.

\section{POPULASI DAN SAMPEL PENELITIAN}

1. Populasi

Populasi yang digunakan dalam penelitian ini adalah jumlah bagi hasil pada pembiayaan mudharabah PT Bank BNI Syariah cabang Makassar perenam bulan dari Januari 2015 sampai dengan Desember 2020.

2. Sampel 
Sampel yang digunakan dalam penelitian ini adalah sampel jenuh (sensus). teknik sampling jenuh adalah teknik penentuan sampel dimana semua anggota populasi digunakan menjadi sampel (Sugiyono:2017). Peneliti hanya meneliti jumlah bagi hasil pada pembiayaan mudharabah PT Bank BNI Syariah cabang Makassar selama 5 Tahun terakhir. Sehingga sampel dalam penelitian ini adalah jumlah bagi hasil pada pembiayaan mudharabah periode $2015-2020$.

\section{E. DEFINISI OPERASIONAL}

1. Bank syariah adalah bank yang beroperasi tanpa mengandalkan bunga. bank syariah juga dapat diartikan sebagai lembaga keuangan yang operasional dan produknya dikembangkan berdasarkan Al-Quran dan Hadis.

2. Bagi hasil dalam sistem perbankan syariah merupakan ciri khusus yang ditawarkan kapada masyarakat, dan di dalam aturan syariah yang berkaitan dengan pembagian hasil usaha harus ditentukan terlebih dahulu pada awal terjadinya kontrak (akad). Besarnya penentuan porsi bagi hasil antara kedua belah pihak ditentukan sesuai kesepakatan bersama, dan harus terjadi dengan adanya kerelaan (An-Tarodhin) di masing-masing pihak tanpa adanya unsur paksaan.

3. Pembiayaan ialah pendanaan yang diberikan oleh suatu pihak kepada pihak lain untuk mendukung investasi yang telah direncanakan, baik dilakukan sendiri maupun lembaga. Dengan kata lain, pembiayaan adalah pendanaan yang dikeluarkan untuk mendukung investasi yang telah direncanakan.

4. Pembiayaan Mudharabah ialah suatu bentuk kerjasama antara kedua belah pihak, dimana pihak pertama yang memberikan seluruh kontribusi dana dan pihak kedua selaku pengelola usaha apabila mengalami keuntungan dibagi sesuai dengan kesepakatan dan apabila mengalami kerugian akan ditanggung oleh pihak pertama.

\section{F. ANALISIS DATA}

Analisis data yang digunakan yakni analisis kulitatif yaitu teknik pengolahan data kualitatif yang dilakukan dalam rangka mendeskripsikan/membahas hasil penelitian dengan pendekatan analisis konseptual dan teoretik.

\section{G. SISTEMATIKA PENULISAN}


Untuk memberikan gambar mengenai keseluruhan penelitian ini, maka penulis memberikan tiap bab yang dibahas sebagai berikut:

Bab pertama merupakan bab pendahuluan, dalam bab ini diuraikan tentang latar belakang, rumusan masalah, tujuan penelitian, dan manfaat penelitian.

Bab kedua merupakan bab tinjauan pustaka, dalam bab ini diuraikan landasan teori dan kerangka pikir

Bab ketiga merupakan bab metode penelitian, bab ini diuraikan lokasi dan waktu penelitian, jenis dan sumber data, teknik pengumpulan data, populasi dan sampel, definisi operasional, analisis data, dan sistematika penulisan.

Bab keempat merupakan bab hasil penelitian dan pembahasan, dalam bab ini diuraikan gambaran umum, unit penelitian dan pembahasan.

Bab kelima merupakan bab penutup, dalam bab ini diuraikan kesimpulan dan saran.

\section{IV.KESIMPULAN}

Penerapan bagi hasil pada pembiayaan mudharabah yang dilakukan PT Bank Negara Indonesia Syariah yaitu menggunakan metode gross profit margin (bagi hasil usaha) untuk rasio pembagian labanya maka pihak PT Bank Negara Indonesia Syariah melihat dari jangka waktu pembiayaan. Pihak Bank tidak meyebutkan berapa porsi antara Bank dan Nasabah melainkan pihak Bank melakukan negosiasi. Jadi penerapan sistem bagi hasil yang diterapkan PT Bank Negara Indonesia Syariah cab Makassar sudah berjalan sesuai dengan fatwa No.07/-DSN-MUI/IV/2000. 
DAFTAR PUSTAKA

Abdullah, A. U. (2017). Penerapan Sistem bagi Hasil pada Pembiayaan Mudharabah di Bank BNI Syariah Cabang Makassar (Doctoral dissertation, Universitas Islam Negeri Alauddin Makassar).

Abdullah, T. (2017). Bank dan Lembaga keuangan.

Daga, R. (2021). ANAlisis STRATEgi PEMASARAN DALAM PENINGKATAN PEMBIAYAAN KONSUMTIF PADA PT BANK RAKYAT INDONESIA SYARIAH, Tbk KANTOR CABANG PEMBANTU GOWA SUNGGUMINASA.

Ilyas, R. (2015). Konsep pembiayaan Dalam perbankan syari’ah. Jurnal Penelitian, 9(1).

Karim, A. A. (2011). Bank Islam: analisis fiqih dan keuangan.

Lewis, M. K., \& Algaoud, L. M. (2003). Perbankan Syariah: prinsip, pratik, dan prospek. Serambi Ilmu Semesta.

Misbach, I. (2019). Bank Syariah: Kualitas Layanan, Kepuasan dan Kepercayaan.

Nuhung, M., \& Marhumi, S. (2018). Analisis Prosedur Pembiayaan Mudharabah Terhadap Peningkatan Pembiayaan Mudharabah Pada PT. Bank Syariah Mandiri Cabang Makassar. Balance, 14(1), 41-50.

Pratama, D. N., Martika, L. D., \& Rahmawati, T. (2017). Pengaruh Pembiayaan Mudharabah, Pembiayaan Musyarakah Dan Sewa Ijarah Terhadap Profitabilitas. Jurnal Riset Keuangan Dan Akuntansi, 3(1).

RASYIDIN, D. (2016). Financing To Deposit Ratio (Fdr) sebagai salah satu penilaian kesehatan Bank Umum Syariah (Study Kasus Pada Bank BJB Syariah Cabang Serang). ISLAMICONOMIC: Jurnal Ekonomi Islam, 7(1).

Suryanti, M. (2019). Penerapan Sistem Bagi Hasil Pembiayaan Mudharabah pada PT. BPRS Aman Syariah Lampung Timur (Doctoral dissertation, IAIN Metro). 
Wahab, W. (2016). Pengaruh tingkat bagi hasil terhadap minat menabung di bank syariah. JEBI (Jurnal Ekonomi dan Bisnis Islam), 1(2), 167-184.

Zainudin, A. (2008). Hukum Perbankan Syariah. Yogyakarta: Sinar Grafika. 
